is unique in this respect) mothers are offered a free choice of analgesia and urged to receive epidural analgesia only if problems in the second stage are expected. Mothers are, moreover, allowed to opt for epidural analgesia when psychoprophylaxis, transcutaneous nerve stimulation, nitrous oxide and oxygen (Entonox), or pethidine, or all four, have been tried and found wanting during prolonged labour. We would hope therefore that few mothers ultimately requiring forceps would not first have received epidural analgesia and some of those few would even then receive a single shot epidural block. With such a policy the nonepidural instrumental delivery rate is extremely low, and it would be fallacious to compare the two populations.

Thus it is possible to judge whether epidurals increase the instrumental delivery rate only by examining the effect of their introduction de novo on the instrumental rate overall (my expression $\mathrm{Mr}$ Husemeyer misunderstands and puts in the most withering quotes). At St Thomas's Hospital the epidural service developed gradually over a decade beginning in the mid-1960s, and its expansion also coincided with the advent of fetal monitoring. We are therefore in no position to answer this question. In Doncaster, however, with the fairly abrupt introduction of an epidural service, the forceps delivery rate rose from $24 \cdot 3 \%$ to $29 \cdot 4 \%$. $^{1}$ This insignificant rise also coincided with the advent of a new obstetrician. Doughty showed how dependent the forceps rate was on the obstetrician, ${ }^{2}$ as no one would dispute. I prefer to leave obstetricians themselves to debate the correct level for the forceps rate.

That "proper" management of the second stage (more of $\mathrm{Mr}$ Husemeyer's disparaging quotes) should include maintaining analgesia, delayed pushing, and supplementing uterine effort with oxytocin is accepted in many informed circles ${ }^{3+}$ in addition to those originally cited, as doubtless my fellow obstetric anaesthetists will confirm.

A high priority is given to the appointment of consultants trained in obstetric anaesthesia, because, as I stated, such individuals are equipped to train junior anaesthetists and teach midwives to provide the high standard of care your correspondents rightly demand. The consultant grade is the only one permitted to expand at present, and any recommendations must surely be within the bounds of possibility.

Drs D L Leaming and R Brown (p 756) are correct in stating that $\mathrm{H}_{2}$ antagonists must be given prophylactically. It is fruitless, however, to give prophylactically a saline antacid whose action is rapid in onset but brief.

FELICITY REYNOLDS

Anaesthetic Unit,
St Thomas's Hospital Medical School,

London SE1 $7 \mathrm{EH}$

1 Bailey PW, Howard FA. Epidural analgesia and forceps delivery: laving a bogev. Anaesthesia 1983;38:282-5

2 Doughty A. Epidural analgesia in labour: the past, the presen and the future. I R Soc Med 1978:71:879-83.

3 Page LJ, Young KR. Uterine activity in the second stage of labour and the effect of epidural analgesia (letter). $\mathrm{Br} \mathcal{F}$ Obstet Gynaecol 1986;93:1017-8.

4 Potter N, McDonald RD. Obstetric consequences of epidural analgesia in nulliparous patients. Lancet 1971;i:1031-4.

\section{Reversible inhibition of leucocyte sodium pumps by a circulating serum factor in essential hypertension}

Sir,-Dr Paola Finotti (13 September, p 697) questions the validity of the conclusions in the paper of Dr V M S Oh and Dr Elizabeth M Taylor (14 June, p 1551). Dr Finotti accepts that intracellular sodium is increased in leucocytes in essential hypertension but then argues that it is not possible to conclude that the sodium efflux rate constant is decreased as no data are presented to show that intracellular sodium is increased. It has repeatedly been shown not only that intracellular sodium is increased in leucocytes in hypertension : but that the cause of this is an abnormal sodium pump. ${ }^{1+68}$ Dr Finotti argues that the demonstration of normal rubidium-86 uptake in the lymphocytes is indicative of normal sodium pump activity. Drs Oh and Taylor have in fact shown that the number of ${ }^{3} \mathrm{H}$-ouabain binding sites is reduced, indicating reduced pump activity, and that the activity of each pump site, as measured by rubidium uptake, is increased. As was pointed out by the authors, this would be the expected result of an increase in cell sodium resulting from abnormally low pump activity. Dr Finotti appears to have fallen into a conceptual trap, common when rubidium uptake is being used as a measure of sodium pump activity. A reduction in the activity of the sodium pumps of a cell leads to an increase in intracellular sodium, the net result being a new steady state in which sodium efflux per cell is unchanged though with the efflux rate constant reduced. As rubidium uptake under these conditions is related not to the rate constant but to sodium efflux this will also be unchanged at the new steady state. Rubidium uptake measured when intracellular sodium is high enough to stimulate the pump maximally yields different information, but those were not the conditions employed in the studies of Drs Oh and Taylor.

LUCILla Poston P J Hilton

Renal Laborator

St Thomas's Hospital,

London SEl

1 Edmondson RPS, Thomas RD, Hilton PJ, Patrick J, Jones NF Abnormal leucocte composition and sodium transport in essential hypertension. Lancet 1975;i:1003-5.

2 Araose MA, Khatri IM, Yao LL, Fries ED. Lcukocyte intracllular cations in hypertension. Effect of antihypertensive drugs. Am Heart 7 1978:96:731-8.

3 Ambrosioni E. Tartagni F, Montebugnoli L, Magnani B. Intralymphocytic sodium in hypertensive patients: a signifIntralymphocytic sodium in hypertensice

4 Poston L, Sewell RB, Wilkinson SP, el al. Evidence for circulating sodium transport inhibitor in essential hypercirculating sodium transport inhibic
tension. BrMcd f 1981:282:847-9.

5 Chien Y-W, Zhao G-S. Abnormal leucocyte sodium transport in Chinese patients with essential hypertension and their normotensive offsprings. Clin Exp Hypertens [A] 1984;6:2279-96.

6 Gray HH, Johnson VE, Poston L, Hilton PJ. Sodium transport by leucocytes and erythrocytes in hypertensive subjects and their normotensive relatives. I Hypertens 1984;2:467-9.

Boon NA, Harper (, Aronson JK, Grahame-Smith DG. Cation transport functions in vitro in patients with untreated essential hypertension: a comparison of erythrocytes and leucocytes. Clin Sci 1985; 68:511-5.

8 Heagerty AM, Milner M, Bing RF, Thurston H, Swales JD. Leucocyte membrane sodium transport in normotensive populations-dissociation of abnormalities of sodium efflux from raised blood-pressure. Lancet 1982;ii:894-6.

\section{The truth about government spending on the} NHS

SIR,-Two recent leading articles have expressed the view that the health service has been severely underfunded over the past seven to eight years (21 June, p 1623; 2 August, p 290). They pointed out that although more money was spent on the health service than eight years ago, even in real terms, this was inadequate. The second showed how, despite the real growth in expenditure on the health service during this period, need had increased faster than this, and it exhorted readers to contact their members of parliament to ask for more funds for the health service.

Before doing so we decided to see how the government's record on health service expenditure compared, not with need, which must inevitably outstrip supply, thanks to technical advances and

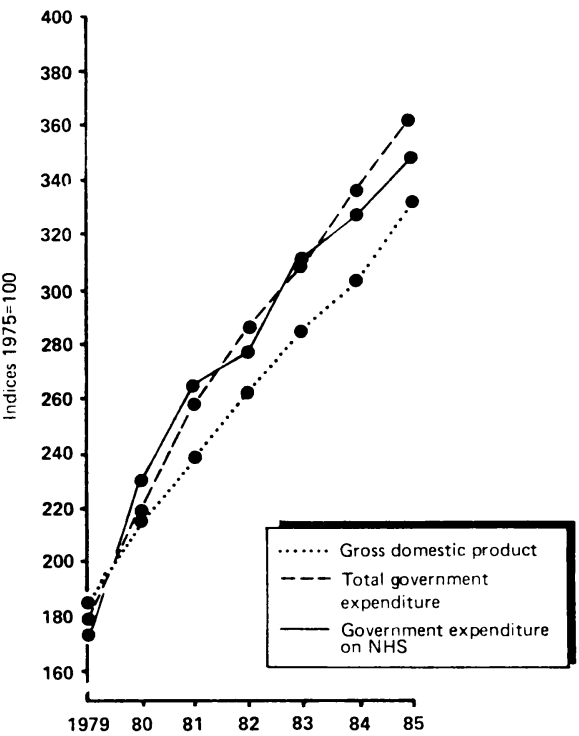

Increases in gross domestic product and government spending 1979-85.

our aging population, but with the money available. We therefore compared health service expenditure with total government expenditure and with the gross domestic product." Between 1975 and 1979 gross domestic product, although growing slowly, went up faster than expenditure on the health service. Since then the pattern of spending has been reversed and National Health Service spending has gone up faster than the gross domestic product. Throughout this period the proportion of government spending on the NHS has remained remarkably constant (figure).

It emerged from these findings that expenditure on the health service could be increased only by increasing the proportion of total government expenditure spent on health or by increased government spending. With the first option the only realistic place that increased spending could come from is defence, and, as none of the three major political parties advocate large decreases in defence spending, this does not seem likely to happen. Increased government spending could be achieved by increasing taxation or increasing the government's borrowing requirements. The Labour party is committed to both, while the Conservatives feel that the benefits of this would be short lived due to the opportunity cost elsewhere in the economy. International comparisons are interesting, and two general rules emerge.

Countries with larger per caput gross domestic products tend to spend a larger proportion of their wealth on health care, Japan being the obvious exception. ${ }^{3}$ Secondly, countries that collect health service money by insurance contributions spend more on health than those that do not. For these reasons people concerned with health should be most concerned to enhance the country's prosperity as a whole. How this might be accomplished is, of course, a matter of personal political philosophy. Those who wish to assess seriously competing economic theories should read detailed texts. Such readers will soon learn that good intentions may have bad consequences for the health and wealth of the nation.

R J LILFORD MaUReEN E DaltoN

Department of Obstetrics and Gynaecology,

St James's University Hospital, Leeds LS9 7TF

Anonvmous. Economic Trends 1986 Julv:6.

2 Anonymous. Monthly Digest of Statistics 1986 July.

3 Maxwell R. An international studv of health care spending. Health and wealth. Lexington, Mass: L exington Books, 1981. 